\title{
Effect of electrodeposition potential on composition and morphology of CIGS absorber thin film
}

\author{
N D SANG ${ }^{\dagger}$, P H QUANG*, L T TU and D T B HOP \\ Hanoi University of Science, Vietnam National University, Hanoi, 334 Nguyen Trai, Thanh Xuan, Hanoi, Vietnam \\ ${ }^{\dagger}$ National University of Civil Engineering, 55 Giai Phong Street, Hai Ba Trung, Hanoi, Vietnam
}

MS received 2 December 2011; revised 23 April 2012

\begin{abstract}
CuInGaSe (CIGS) thin films were deposited on Mo/soda-lime glass substrates by electrodeposition at different potentials ranging from $-\mathbf{0 . 3}$ to $-1.1 \mathrm{~V}$ vs $\mathrm{Ag} / \mathrm{AgCl}$. Cyclic voltammetry (CV) studies of unitary $\mathrm{Cu}$, $\mathrm{Ga}$, In and Se systems, binary $\mathrm{Cu}-\mathrm{Se}$, Ga-Se and In-Se systems and quaternary $\mathrm{Cu}-\mathrm{In}-\mathrm{Ga}-\mathrm{Se}$ were carried out to understand the mechanism of deposition of each constituent. Concentration of the films was determined by energy dispersive spectroscopy. Structure and morphology of the films were characterized by $\mathrm{X}$-ray diffraction and scanning electron microscope. The underpotential deposition mechanism of $\mathrm{Cu}-\mathrm{Se}$ and $\mathrm{In}-\mathrm{Se}$ phases was observed in voltammograms of binary and quaternary systems. Variation in composition with applied potentials was explained by cyclic voltammetry (CV) data. A suitable potential range from -0.8 to $-1.0 \mathrm{~V}$ was found for obtaining films with desired and stable stoichiometry. In the post-annealing films, chalcopyrite structure starts forming in the samples deposited at $\mathbf{- 0 . 5} \mathrm{V}$ and grows on varying the applied potential towards negative direction. By adjusting the composition of electrolyte, we obtained the desired stoichiometry of $\mathrm{Cu}\left(\operatorname{In}_{0.7} \mathrm{Ga}_{0.3}\right) \mathrm{Se}_{2}$.
\end{abstract}

Keywords. Thin films; cyclic voltammetry; CuInGaSe (CIGS); solar cell; electrodeposition.

\section{Introduction}

$\mathrm{Cu}\left(\mathrm{In}_{1-x} \mathrm{Ga}_{x}\right) \mathrm{Se}_{2}$ (CIGS) thin film has potential as an absorber material for solar cell application because it has a large optical absorption coefficient $\left(5 \times 10^{5} \mathrm{~cm}^{-1}\right)$ which results from the direct bandgap (Bhatacharya et al 1998; Hermann et al 1998). CIGS basethin film solar cell has reached a conversion efficiency of $19.9 \%$ for laboratorysize devices fabricated from a physical vapour deposition (PVD) process (Repinst et al 2008). Additionally, CIGS modules have shown a long-term stability without any signs of degradation (Bhatacharya et al 1998; Hermann et al 1998). In order to make CIGS-based solar cell become more realizable, an alternative low-cost process has to be developed for the growth of high-quality CIGS absorber layer. Electrodeposition technique is potentially suitable to satisfy this requirement. Recently, there has been a number of reports on the growth of CIGS thin film using electrodeposition technique. A conversion efficiency as high as $15.4 \%$ has been achieved in the devices with CIGS film grown by electrodeposition and the composition adjusted by PVD (Bhatacharya et al 2000). There are two different electrochemical approaches to form CIGS films: one-step electrodeposition (Zank et al 1996; Kampmann et al 2000; Zhang et al 2003; Fernandez and Bhatacharya 2005; Kang et al 2010) that provides all constituents from the same

\footnotetext{
*Author for correspondence (phquang2711@yahoo.com)
}

electrolyte in a single-step and multi-step electrodeposition that deposits sequentially each constituent from different electrolytes (Friedfeld et al 1999; Kampmann et al 2003). However, one-step electrodeposition of CIGS films is rather difficult due to large difference in the values of equilibrium reduction potential for each constituent. In this technique, to achieve a desired film composition, a balancing of fluxes of the constituents can be done by adjusting the concentration in the solution as well as deposition potential. In this investigation, we study the deposition mechanism of the constituents by using cyclic voltammetry (CV) technique. We also grow CIGS thin films on $\mathrm{Mo} /$ soda-lime glass substrates by electrodeposition at different potentials ranging from -0.3 to $-1.1 \mathrm{~V}$ vs $\mathrm{Ag} / \mathrm{AgCl}$. The aim of this work is mainly to find out the appropriate deposition potential in one-step electrodeposition of CIGS layer. However, based on the understanding of electrodeposition mechanism of different constituents, we also made an attempt to vary the concentration of electrolyte for matching the stoichiometry of $\mathrm{Cu}\left(\mathrm{In}_{0.7} \mathrm{Ga}_{0.3}\right) \mathrm{Se}_{2}$.

\section{Experimental}

CV studies and potentiostatic electrodeposition (ED) process were carried out using a potentiostat/galvanostat model Autolab $3020 \mathrm{~N}$ in a three-electrode configuration where the reference electrode was $\mathrm{Ag} / \mathrm{AgCl}$, the counter electrode was a Pt spiral wire and the working electrode was 
a Mo/soda-lime glass substrate with an area of $1.5 \mathrm{~cm}^{2}$. Mo layer was deposited by d.c. sputtering with a thickness of $1 \mu \mathrm{m}$ and resistivity of $15 \mu \Omega \mathrm{cm}$. The electrolyte bath contained $120 \mathrm{ml}$ deionized water, $20 \mathrm{mM} \mathrm{CuCl}_{2}$, $30 \mathrm{mM} \mathrm{InCl}_{3}, 40 \mathrm{mM} \mathrm{Ga}\left(\mathrm{NO}_{3}\right)_{3}, 20 \mathrm{mM} \mathrm{H}_{2} \mathrm{SeO}_{3}$ and $350 \mathrm{mM} \mathrm{LiCl}$. A combination of $25 \mathrm{mM}$ potassium hydrogen phthalate (KHP) and $20 \mathrm{mM} \mathrm{H}_{3} \mathrm{SNO}_{3}$ (sulphamic acids) was used as a complexing agent. In our previous study (not published yet), we have found that this concentration of complexing agent was the best choice. $\mathrm{pH}$ of the solution was adjusted to 2.0 by adding drops of concentrated hydrochloric acid. CV was carried out in the range of potentials from -1.2 to $0.0 \mathrm{~V}$ vs $\mathrm{Ag} / \mathrm{AgCl}$ at a scan rate of $20 \mathrm{mV} / \mathrm{s}$. The first scan was in negative direction. EDs were processed at the potentials ranging from -0.3 to $-1.1 \mathrm{~V}$ vs $\mathrm{Ag} / \mathrm{AgCl}$ for $20 \mathrm{~min}$. The annealing process was carried out in $\mathrm{Ar}$ at $550{ }^{\circ} \mathrm{C}$ for $60 \mathrm{~min}$. Concentration of the films grown by ED was determined by energy dispersive spectroscopy (EDS), surface morphology was examined by scanning electron microscope (SEM) and crystallinity was examined by X-ray diffraction (XRD).

\section{Results and discussion}

\subsection{Voltammogram of unitary $\mathrm{Cu}, \mathrm{Ga}$, In and Se systems}

Figure 1(a) shows voltammogram of the base solution which contains only water, $\mathrm{LiCl}, \mathrm{KHP}$ and $\mathrm{H}_{3} \mathrm{SNO}_{3}$. As seen in the figure, within the scan range, there is no reduction peak. It means that any reduction process does not take place in this solution. At high negative potential, the current decreases rapidly when hydrogen reduction starts occurring. Figure 1(b) presents the voltammogram of $20 \mathrm{mM} \mathrm{CuCl}_{2}$ in the solution. In this voltammogram, we can see one weak peak at about $0.15 \mathrm{~V}$, one peak at about $-0.4 \mathrm{~V}$ and one peak at $-0.9 \mathrm{~V}$ vs $\mathrm{Ag} / \mathrm{AgCl}$. We suggest that the peak at $0.15 \mathrm{~V}$ relates to the process:

$$
\mathrm{Cu}^{2+}+2 \mathrm{Cl}^{-}+e^{-} \leftrightarrow \mathrm{CuCl}_{2}^{-} .
$$

Our suggestion is in agreement with the proposal by Abrantes et al (1995).

The peak at $-0.4 \mathrm{~V}$ may be assigned to the process:

$$
\mathrm{Cu}^{2+}+2 e^{-} \leftrightarrow \mathrm{Cu}^{0} .
$$

Although it is well known that $\mathrm{Cu}$ deposition is a reversible process, we do not observe an oxidation peak corresponding to this reduction peak. This feature can be explained by the formation of complexation between sulphamate anions and cuprous cations. The peak at $-0.9 \mathrm{~V}$ should be assigned to the $\mathrm{H}^{+}$reduction to $\mathrm{H}_{2}$ process. All our attributions of the peaks in voltammogram of $\mathrm{Cu}$ unitary system are in very good agreement with those reported by Liu et al (2011) and Lai et al (2009).

Figure 1(c) presents voltammogram of the solution containing $30 \mathrm{mM} \mathrm{InCl}$. In this figure, the reduction of $\mathrm{In}^{3+}$

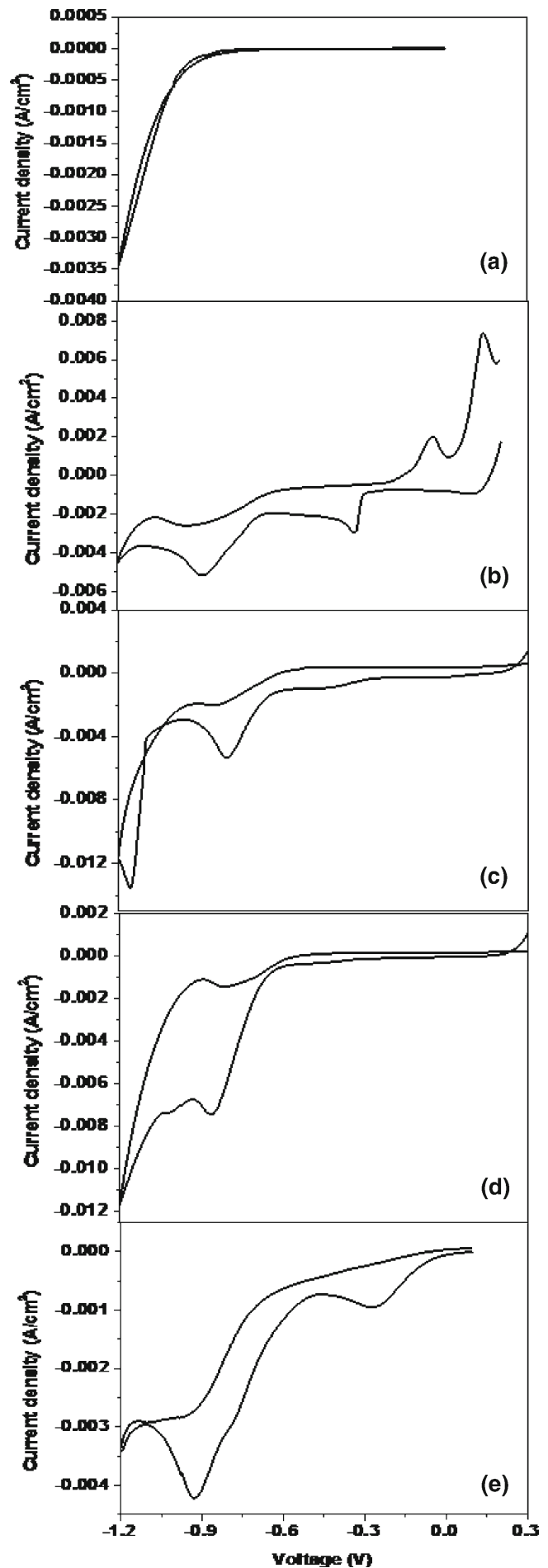

Figure 1. Voltammograms of (a) base solution containing water, $\mathrm{LiCl}, \mathrm{KHP}$ and $\mathrm{H}_{3} \mathrm{SNO}_{3}$; (b) solution containing $20 \mathrm{mM} \mathrm{CuCl} 2$; (c) solution containing $30 \mathrm{mM} \mathrm{InCl}_{3}$; (d) solution containing $40 \mathrm{mM} \mathrm{Ga}\left(\mathrm{NO}_{3}\right)_{3}$ and (e) solution containing $20 \mathrm{mM} \mathrm{H}_{2} \mathrm{SeO}_{3}$.

to In reaches a maximum at $-0.8 \mathrm{~V}$. The voltammogram of the solution containing $40 \mathrm{mM} \mathrm{Ga}\left(\mathrm{NO}_{3}\right)_{3}$ is shown in figure 1(d). Similar to the In system, the peak at $-0.9 \mathrm{~V}$ can be attributed to the reduction of $\mathrm{Ga}^{3+}$ to $\mathrm{Ga}$. We can see that although the concentration of the $\mathrm{Ga}\left(\mathrm{NO}_{3}\right)_{3}$ is $40 \mathrm{mM}$, 
higher than those of other constituents, the current density is rather low. It again indicates that among four elements $\mathrm{Ga}$ has the most negative reduction potential and therefore, is the most difficult element to deposit. The voltammogram of $\mathrm{H}_{2} \mathrm{SeO}_{3}$ presented in figure 1(e) shows two strong peaks, one at $-0.3 \mathrm{~V}$ and the other at $-0.9 \mathrm{~V}$ vs $\mathrm{Ag} / \mathrm{AgCl}$. The first peak is likely related to the reduction of $\mathrm{H}_{2} \mathrm{SeO}_{3}$ directly to Se, following the equation:

$$
\mathrm{H}_{2} \mathrm{SeO}_{3}+4 \mathrm{H}^{+}+4 e^{-} \leftrightarrow \mathrm{Se}+3 \mathrm{H}_{2} \mathrm{O}
$$

We suggest the second peak corresponding to the complex process described by the equations:

$$
\begin{aligned}
& \mathrm{H}_{2} \mathrm{SeO}_{3}+6 \mathrm{H}^{+}+6 e^{-} \leftrightarrow \mathrm{H}_{2} \mathrm{Se}+3 \mathrm{H}_{2} \mathrm{O}, \\
& \mathrm{H}_{2} \mathrm{SeO}^{3}+2 \mathrm{H}_{2} \mathrm{Se}+6 e^{-} \leftrightarrow \mathrm{Se}+3 \mathrm{H}_{2} \mathrm{O} .
\end{aligned}
$$

This suggestion is similar to those reported by Massaccesi et al (1996) and Mishra and Rajeshwar (1989).

\subsection{Voltammogram of binary $\mathrm{Cu}-\mathrm{Se}, \mathrm{Ga}-\mathrm{Se}$ and In-Se}

Figure 2(a) illustrates voltammogram of the electrolyte solution containing $20 \mathrm{mM} \mathrm{CuCl}_{2}$ and $20 \mathrm{mM} \mathrm{H}_{2} \mathrm{SeO}_{3}$. The peak at $-0.9 \mathrm{~V}$ is still assigned to the reduction processes of $\mathrm{H}_{2} \mathrm{SeO}_{3}$ which have been described in the preceding section. There are some differences between this voltammogram and those of unitary $\mathrm{Cu}$ and $\mathrm{Se}$ systems. The first notable difference is the appearance of the second peak at $-0.7 \mathrm{~V}$. This peak may still relate to the processes described by (4) and (5), i.e., these processes occur at a more positive potential. Liu et al (2011) has also observed this behaviour and attributed it to the reduction of $\mathrm{Se}$ to $\mathrm{H}_{2} \mathrm{Se}$, according to the equation:

$$
\mathrm{Se}+2 \mathrm{H}^{+}+2 e^{-} \leftrightarrow \mathrm{H}_{2} \mathrm{Se} .
$$

In their report, the significant positive shift from -0.9 to $-0.65 \mathrm{~V}$ of this reduction peak has been explained by the release of formation free energy from the reaction:

$$
\mathrm{Se}+\mathrm{Cu}^{2+} \leftrightarrow \mathrm{CuSe}+2 \mathrm{H}^{+} .
$$

Another notable difference is the positive shift of either the peak described by (2) or the one described by (3) from their former position where $\mathrm{Cu}^{2+}$ or $\mathrm{Se}^{4+}$ alone is reduced to the position of $-0.1 \mathrm{~V}$. According to Thouin et al (1993) the origin of this phenomenon can be attributed to the formation of a $\mathrm{Cu}-\mathrm{Se}$ phase, for example:

$$
\begin{aligned}
& 2 \mathrm{Cu}^{+}+\mathrm{H}_{2} \mathrm{SeO}_{3}+4 \mathrm{H}^{+}+6 e^{-} \leftrightarrow \mathrm{Cu}_{2} \mathrm{Se}+3 \mathrm{H}_{2} \mathrm{O}, \\
& \mathrm{Cu}^{2+}+\mathrm{H}_{2} \mathrm{SeO}_{3}+4 \mathrm{H}^{+}+6 e^{-} \leftrightarrow \mathrm{CuSe}+3 \mathrm{H}_{2} \mathrm{O} .
\end{aligned}
$$

Figure 2(b) shows voltammogram of solution containing $30 \mathrm{mM} \mathrm{InCl}_{3}$ and $20 \mathrm{mM} \mathrm{H}_{2} \mathrm{SeO}_{3}$. By comparing this voltammogram with those of unitary In and Se systems, we can attribute the first peak at $-0.3 \mathrm{~V}$ to the reduction of

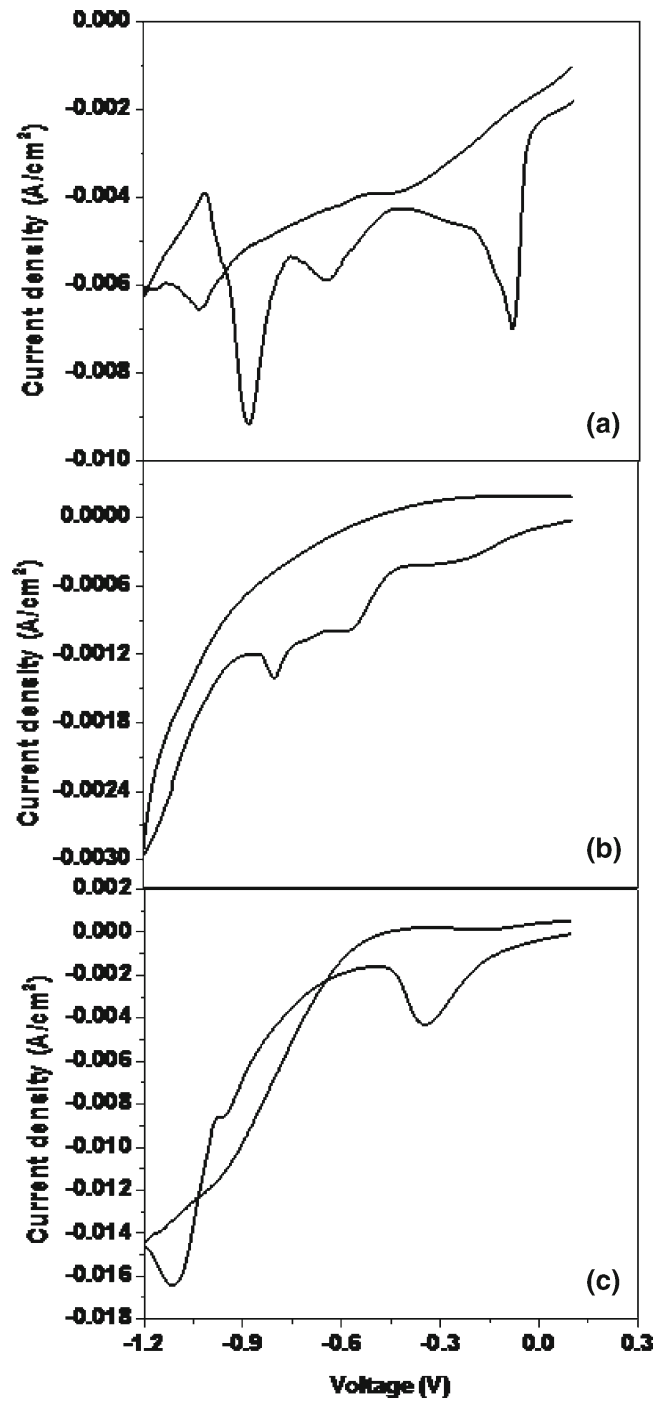

Figure 2. Voltammograms of (a) solution containing $20 \mathrm{mM}$ $\mathrm{CuCl}_{2}$ and $20 \mathrm{mM} \mathrm{H}_{2} \mathrm{SeO}_{3}$; (b) solution containing $30 \mathrm{mM} \mathrm{InCl} 3$ and $20 \mathrm{mM} \mathrm{H}_{2} \mathrm{SeO}_{3}$ and (c) solution containing $40 \mathrm{mM} \mathrm{Ga}\left(\mathrm{NO}_{3}\right)_{3}$ and $20 \mathrm{mM} \mathrm{H}_{2} \mathrm{SeO}_{3}$.

$\mathrm{H}_{2} \mathrm{SeO}_{3}$ directly to $\mathrm{Se}$ and the second peak at $-0 \cdot 8 \mathrm{~V}$ to the reduction of $\mathrm{In}^{3+}$ to $\mathrm{In}$. Besides that, we can observe one peak at $-0.57 \mathrm{~V}$ which may relate to an underpotential deposition of indium as indium selenides. This process can be described by the equation:

$$
3 \mathrm{Se}+2 \operatorname{In}^{3+}+6 e^{-} \leftrightarrow \operatorname{In}_{2} \mathrm{Se}_{3} .
$$

For the case of voltammogram of binary Ga-Se system, we only see one peak at $-0 \cdot 3 \mathrm{~V}$ which corresponds to the reduction of $\mathrm{H}_{2} \mathrm{SeO}_{3}$ directly to $\mathrm{Se}$ and one peak at $-0.95 \mathrm{~V}$ which corresponds to the reduction of $\mathrm{Ga}^{3+}$ to $\mathrm{Ga}$. It means that the underpotential deposition of gallium as gallium selenides do not occur in this system. Furthermore, the presence of $\mathrm{Ga}^{3+}$ in the solution has inhibited the complex process described by (4) and (5). 


\subsection{Voltammogram of quaternary $\mathrm{Cu}-\mathrm{In}-\mathrm{Ga}-\mathrm{Se}$}

Figure 3 is the voltammogram for solution containing $20 \mathrm{mM}$ $\mathrm{CuCl}_{2}, 40 \mathrm{mM} \mathrm{Ga}\left(\mathrm{NO}_{3}\right)_{3}, 30 \mathrm{mM} \mathrm{InCl}_{3}$ and $20 \mathrm{mM} \mathrm{H}_{2} \mathrm{SeO}_{3}$. Again, we can observe a peak at $-0.1 \mathrm{~V}$ which should be assigned to the formation of a $\mathrm{Cu}-\mathrm{Se}$ phase as described above. We can also see a weak peak at $-0.9 \mathrm{~V}$ which should correspond to the reduction of $\mathrm{Ga}^{3+}$ to $\mathrm{Ga}$ and/or the complex reduction of $\mathrm{H}_{2} \mathrm{SeO}_{3}$. The most notable feature in this voltammogram is a strong peak at $-0.5 \mathrm{~V}$. This peak may relate to one of the underpotential depositions described by (6) or (10). It is not easy to distinguish well which process this peak corresponds to. In order to elucidate this problem, further studies are needed. However, we can say that the underpotential deposition mechanism of $\mathrm{Cu}-\mathrm{Se}$ and In-Se phases has occurred. This voltammogram also reveals that deposition of Ga still needs a highly negative potential.

\subsection{Potential dependence of composition}

EDS composition of the CIGS films deposited at various potentials is listed in table 1 . Generally, the potential dependence of the composition is in accordance with the $\mathrm{CV}$ results. First of all, the concentration of $\mathrm{Cu}$ increases as the deposition potential decreases to $-0.5 \mathrm{~V}$, then decreases as the deposition potential decreases continuously. The maximum value of $\mathrm{Cu}$ concentration at $-0.5 \mathrm{~V}$ should associate to the reduction process of $\mathrm{Cu}^{2+}$ to $\mathrm{Cu}^{0}$ at $-0.4 \mathrm{~V}$ (2) as well as to the low concentration of In and $\mathrm{Ga}$ in the samples deposited at potentials less negative than $-0.5 \mathrm{~V}$.

Concerning the Ga concentration, we can see that it has very low value in the samples deposited at the negative potential above $-0.7 \mathrm{~V}$, then rises rapidly as the potential decreases and reaches to a maximum value of $18.14 \%$ at the potential of $-1.0 \mathrm{~V}$. This trend in variation of Ga concentration can be expected from the $\mathrm{CV}$ data which show the reduction of $\mathrm{Ga}$ at $-0.9 \mathrm{~V}$. In the case of $\mathrm{In}$, the insertion of

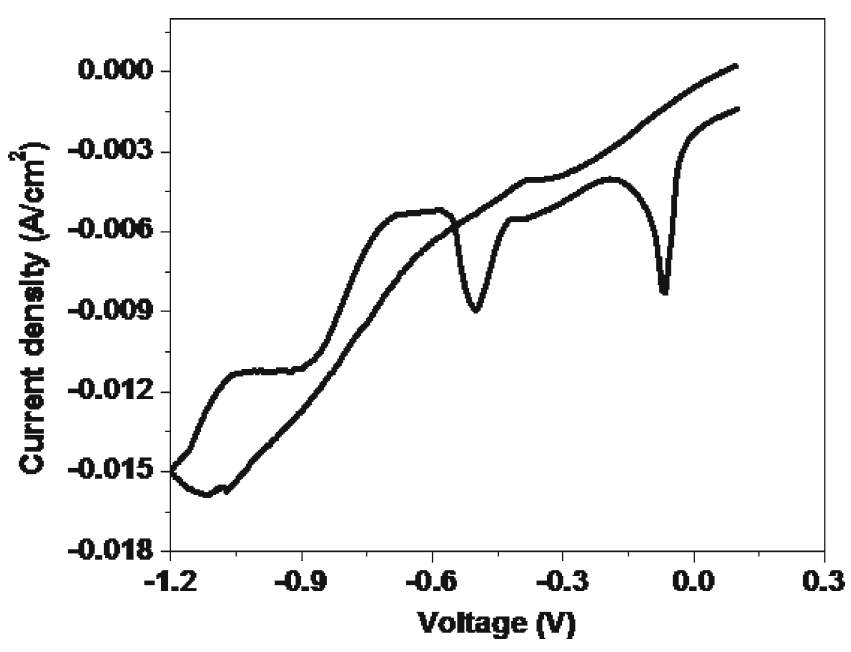

Figure 3. Voltammogram of solution containing $20 \mathrm{mM} \mathrm{CuCl}_{2}$, $30 \mathrm{mM} \mathrm{InCl}_{3}, 40 \mathrm{mM} \mathrm{Ga}\left(\mathrm{NO}_{3}\right)_{3}$ and $20 \mathrm{mM} \mathrm{H}_{2} \mathrm{SeO}_{3}$.
In can be achieved at $-0.5 \mathrm{~V}$, that is more positive than the desired deposition potential for $\mathrm{Ga}$. This feature may have two reasons, the reduction potential of $\mathrm{In}^{3+}$ to In is more positive than that for the reduction of $\mathrm{Ga}^{3+}$ to $\mathrm{Ga}$ and the underpotential deposition of indium as indium selenides occurs in the co-electrodeposition of In and Se.

Se concentration is high in all samples and depends mainly on the concentration of the other constituents. This result reveals that the deposition of Se can take place at the whole range of the investigated potential. We can expect this phenomenon from the facts that Se has two wide reduction peaks and the ability to form an intermediate phase with other constituents by underpotential deposition mechanism. It is interesting to note that there is a range of potentials from -0.8 to $-1.0 \mathrm{~V}$ where the concentration of all the constituents is quite unaffected by the potential. This potential range is also where we can obtain the highest concentration of In and Ga. It means that this potential range is the best choice for obtaining films with desired and stable stoichiometry. Our observation about the suitable potential range is in agreement with that reported by Lai et al (2009).

Since CIGS films deposited by electrodeposition generally need an annealing process, evaluation of composition of the films after annealing is necessary. Three samples deposited at $-0.8,-0.9$ and $-1.0 \mathrm{~V}$ were annealed in $\mathrm{Ar}$ at $550{ }^{\circ} \mathrm{C}$ for 60 min. We chose these samples because we considered that they were the best ones in terms of In and Ga concentrations. EDS composition of these films are listed in table 2. We can

Table 1. EDS composition of CIGS films deposited at various potentials.

\begin{tabular}{|c|c|c|c|c|c|}
\hline \multirow{2}{*}{$\begin{array}{l}\text { Potential } \\
\text { (V vs } \mathrm{Ag} / \mathrm{AgCl})\end{array}$} & \multicolumn{4}{|c|}{ Atomic percent $(\%)$} & \multirow[b]{2}{*}{ Stoichiometry } \\
\hline & $\mathrm{Cu}$ & In & $\mathrm{Ga}$ & $\mathrm{Se}$ & \\
\hline$-0 \cdot 3$ & 23.9 & $03 \cdot 3$ & $01 \cdot 9$ & $70 \cdot 9$ & $\mathrm{CuIn}_{0.14} \mathrm{Ga}_{0.08} \mathrm{Se}_{2.96}$ \\
\hline$-0 \cdot 4$ & $25 \cdot 7$ & $04 \cdot 6$ & $02 \cdot 0$ & $67 \cdot 7$ & $\mathrm{CuIn}_{0 \cdot 18} \mathrm{Ga}_{0.08} \mathrm{Se}_{2.63}$ \\
\hline$-0 \cdot 5$ & $27 \cdot 0$ & $10 \cdot 2$ & $02 \cdot 3$ & $60 \cdot 5$ & $\mathrm{CuIn}_{0.37} \mathrm{Ga}_{0.08} \mathrm{Se}_{2.24}$ \\
\hline-0.6 & 22.7 & $16 \cdot 5$ & 02.9 & $57 \cdot 9$ & $\mathrm{CuIn}_{0.73} \mathrm{Ga}_{0.13} \mathrm{Se}_{2.56}$ \\
\hline-0.7 & $19 \cdot 8$ & $19 \cdot 5$ & $06 \cdot 0$ & $54 \cdot 7$ & $\mathrm{CuIn}_{0.98} \mathrm{Ga}_{0.30} \mathrm{Se}_{2.76}$ \\
\hline$-0 \cdot 8$ & $18 \cdot 2$ & $23 \cdot 7$ & $08 \cdot 7$ & $49 \cdot 4$ & $\mathrm{CuIn}_{1.30} \mathrm{Ga}_{0.47} \mathrm{Se}_{2.70}$ \\
\hline$-0 \cdot 9$ & $18 \cdot 0$ & $22 \cdot 4$ & $13 \cdot 4$ & $46 \cdot 2$ & $\mathrm{CuIn}_{1.24} \mathrm{Ga}_{0.74} \mathrm{Se}_{2.56}$ \\
\hline$-1 \cdot 0$ & $17 \cdot 5$ & $22 \cdot 1$ & $14 \cdot 1$ & $46 \cdot 3$ & $\mathrm{CuIn}_{1.26} \mathrm{Ga}_{0.80} \mathrm{Se}_{2.64}$ \\
\hline$-1 \cdot 1$ & $17 \cdot 0$ & $21 \cdot 8$ & $13 \cdot 2$ & $48 \cdot 0$ & $\mathrm{CuIn}_{1.28} \mathrm{Ga}_{0.77} \mathrm{Se}_{2.81}$ \\
\hline
\end{tabular}

Table 2. EDS composition of post-annealed films deposited at $-0.8,-0.9$ and $-1.0 \mathrm{~V}$ from electrolyte bath containing $20 \mathrm{mM}$ $\mathrm{CuCl}_{2}, 30 \mathrm{mM} \mathrm{InCl}_{3}, 40 \mathrm{mM} \mathrm{Ga}\left(\mathrm{NO}_{3}\right)_{3}$ and $20 \mathrm{mM} \mathrm{H}_{2} \mathrm{SeO}_{3}$.

\begin{tabular}{lccccc} 
& \multicolumn{4}{c}{ Atomic percent $(\%)$} & \\
\cline { 2 - 5 } $\begin{array}{l}\text { Potential } \\
(\mathrm{V} \text { vs Ag/AgCl) }\end{array}$ & $\mathrm{Cu}$ & $\mathrm{In}$ & $\mathrm{Ga}$ & $\mathrm{Se}$ & Stoichiometry \\
\hline-0.8 & 19.5 & 25.2 & 09.5 & 45.8 & $\mathrm{CuIn}_{1 \cdot 29} \mathrm{Ga}_{0.48} \mathrm{Se}_{2.35}$ \\
-0.9 & 19.4 & 23.6 & 13.8 & 43.2 & $\mathrm{CuIn}_{1.22} \mathrm{Ga}_{0.71} \mathrm{Se}_{2 \cdot 23}$ \\
-1.0 & 18.7 & 23.5 & 14.3 & 43.5 & $\mathrm{CuIn}_{1.25} \mathrm{Ga}_{0.76} \mathrm{Se}_{2.32}$ \\
\hline
\end{tabular}


see that the most significant difference between the composition of these films and those of as-deposited films is the decrease in Se content. This difference is due to the higher evaporation rate of $\mathrm{Se}$ compared to those of $\mathrm{Cu}$, In and $\mathrm{Ga}$.

Table 3. EDS composition of post-annealed films deposited at $-0.8,-0.9$ and $-1.0 \mathrm{~V}$ from electrolyte bath containing $20 \mathrm{mM}$ $\mathrm{CuCl}_{2}, 20 \mathrm{mM} \mathrm{InCl}_{3}, 30 \mathrm{mM} \mathrm{Ga}\left(\mathrm{NO}_{3}\right)_{3}$ and $20 \mathrm{mM} \mathrm{H}_{2} \mathrm{SeO}_{3}$.

\begin{tabular}{lccccc}
\hline \multirow{2}{*}{$\begin{array}{l}\text { Potential } \\
(\mathrm{V} \text { vs Ag/AgCl) }\end{array}$} & \multicolumn{4}{c}{ Atomic percent $(\%)$} & \\
\cline { 2 - 5 } & $\mathrm{Cu}$ & $\mathrm{In}$ & $\mathrm{Ga}$ & $\mathrm{Se}$ & Stoichiometry \\
\hline-0.8 & 25.5 & 17.7 & 6.2 & 50.6 & $\mathrm{CuIn}_{0.69} \mathrm{Ga}_{0.24} \mathrm{Se}_{1.98}$ \\
-0.9 & 24.8 & 16.9 & 9.6 & 48.7 & $\mathrm{CuIn}_{0.68} \mathrm{Ga}_{0.38} \mathrm{Se}_{1.96}$ \\
-1.0 & 24.2 & 15.6 & 10.5 & 49.7 & $\mathrm{CuIn}_{0.64} \mathrm{Ga}_{0.43} \mathrm{Se}_{2.05}$ \\
\hline
\end{tabular}

On noting that the main deviation of the composition of these films from the desired stoichiometry of $\mathrm{Cu}\left(\mathrm{In}_{0.7} \mathrm{Ga}_{0.3}\right) \mathrm{Se}_{2}$ was the high concentration of In and $\mathrm{Ga}$, and we deposited the other three films, also at the potentials of $-0.8,-0.9$ and $-1.0 \mathrm{~V}$, but from a new electrolyte bath and which contained $20 \mathrm{mM} \mathrm{CuCl}_{2}, 20 \mathrm{mM} \mathrm{InCl}_{3}, 30 \mathrm{mM}$ $\mathrm{Ga}\left(\mathrm{NO}_{3}\right)_{3}$ and $20 \mathrm{mM} \mathrm{H}_{2} \mathrm{SeO}_{3}$. The films were also annealed in $\mathrm{Ar}$ at $550{ }^{\circ} \mathrm{C}$ for $60 \mathrm{~min}$. EDS composition of these films after annealing are listed in table 3 , showing clearly an improvement in matching the desired stoichiometry.

\subsection{Morphology and crystallinity}

Figure 4 is the cross-sectional and surface morphology (SEM) of typical as-deposited samples, namely, the ones deposited at $-0.3,-0.6$ and $-0.9 \mathrm{~V}$. As seen, these

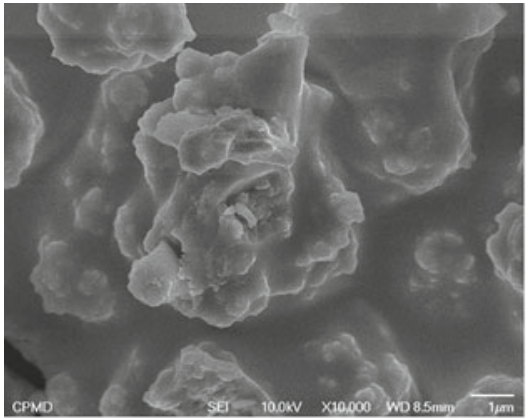

a
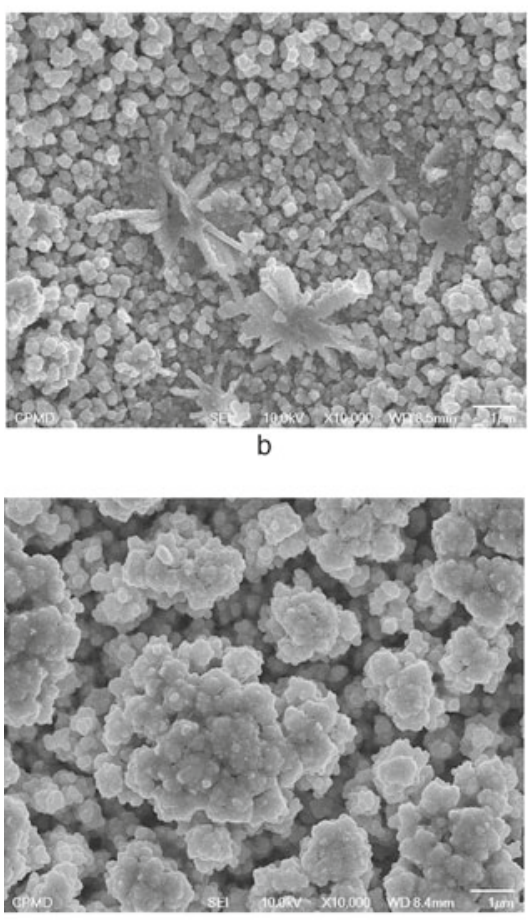

C

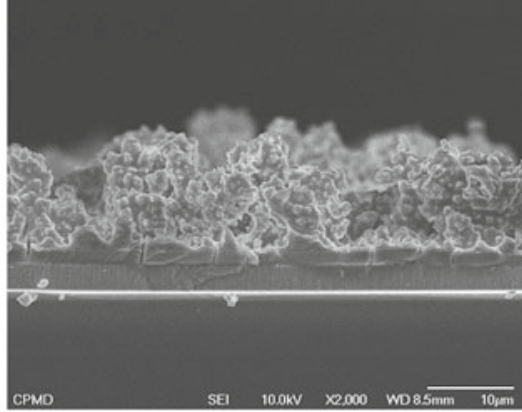

$a^{\prime}$

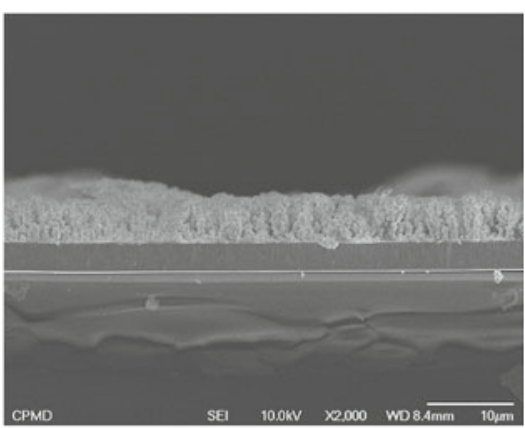

b'

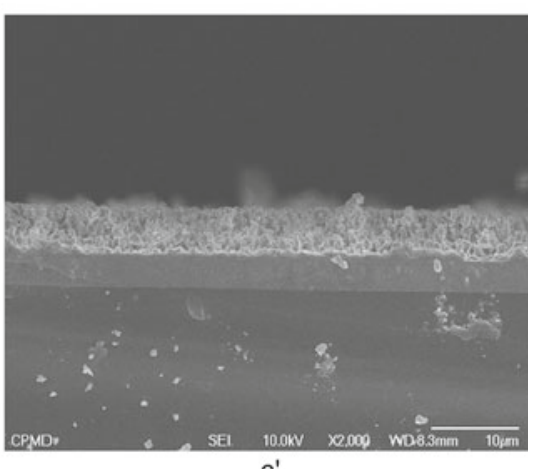

Figure 4. Cross-sectional and surface morphology (SEM) of typical as-deposited samples deposited at $\left(\mathrm{a}, \mathrm{a}^{\prime}\right)-0.3 \mathrm{~V},\left(\mathrm{~b}, \mathrm{~b}^{\prime}\right)-0.6 \mathrm{~V}$ and $\left(\mathrm{c}, \mathrm{c}^{\prime}\right)-0.9 \mathrm{~V}$ vs $\mathrm{Ag} / \mathrm{AgCl}$. 
films have poor crystallinity with porous, non-uniform and polyphasic structure. However, these micrographs also indicate that the samples deposited at less negative potential are more dense and compact. This is because these samples consist mainly of the phases containing $\mathrm{Cu}$ and $\mathrm{Se}$.

The effect of annealing process on the morphology and crystallinity of the samples can be seen in figure 5. We can see clearly that these films are more dense and compact. The most significant difference between the as-deposited and the post-annealed films is the change in the shape of the grains, i.e. from cauliflower-like to flake-like. This is a clear evidence of crystallization occurring during annealing process.

Evolution of morphology and crystallinity under the variation of applied potential and the annealing process can be seen more from the XRD results which are shown in figure 6. In all cases of as-deposited samples, XRD patterns exhibit a nanocrystalline and/or amorphous structure. For that reason, we show only one pattern of a typical as-deposited sample. XRD patterns of the post-annealed samples reveal that these films have a better crystalline structure. Typical peaks of the chalcopyrite structure, viz. (112), (220) and (312) start appearing in the XRD pattern of the sample deposited at $-0.5 \mathrm{~V}$, the intensity of these peaks increases with the change in applied potential towards negative direction and then becomes strongly dominant in the XRD pattern of the film deposited at $-0.9 \mathrm{~V}$. In the XRD pattern of this film (pattern d), we can also see some very weak peaks. However, these peaks can still be identified as the peaks of chalcopyrite structure and are indexed

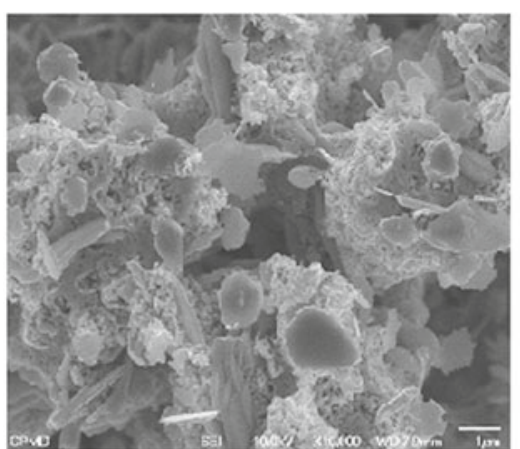

a

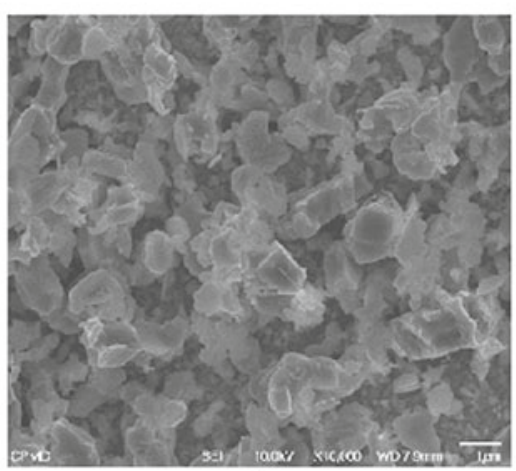

b

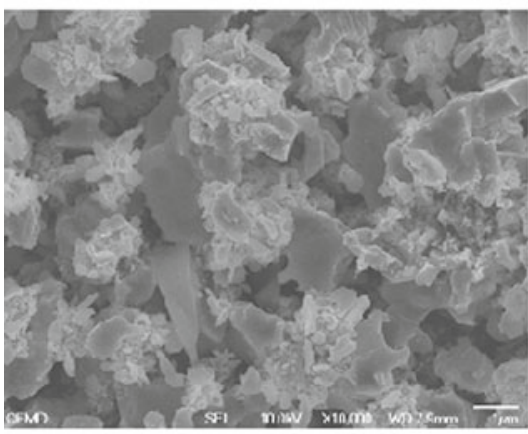

C

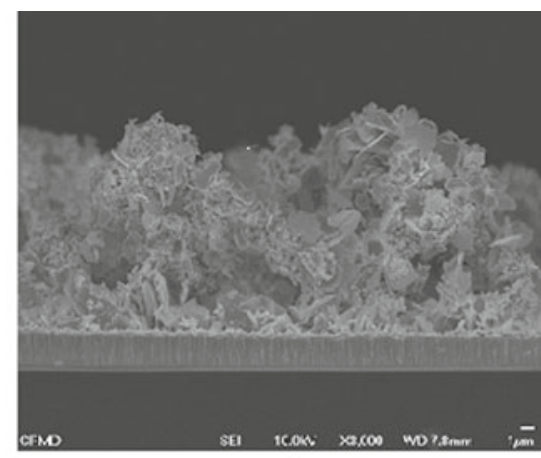

$a^{\prime}$
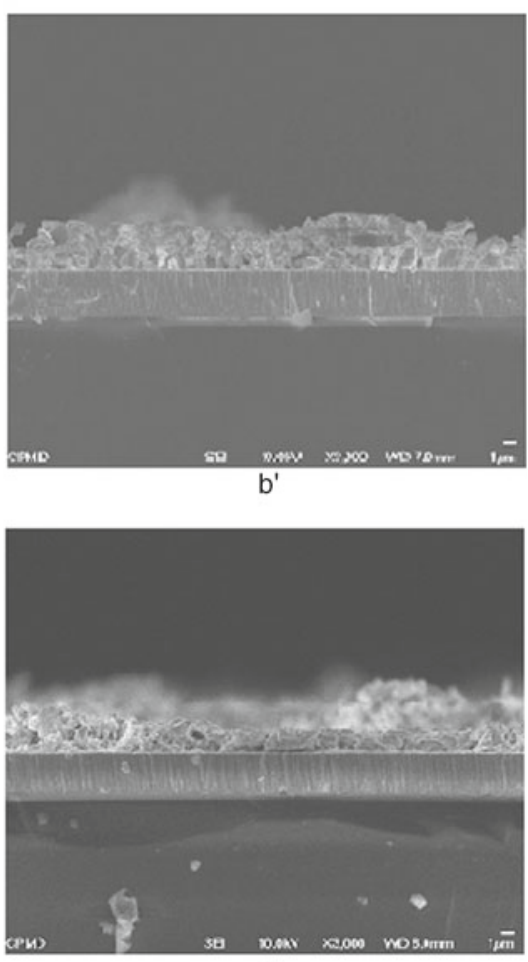

Figure 5. Cross-sectional and surface morphology (SEM) of samples deposited at $\left(\mathrm{a}, \mathrm{a}^{\prime}\right)-0.3 \mathrm{~V},\left(\mathrm{~b}, \mathrm{~b}^{\prime}\right)-0.6 \mathrm{~V}$ and $\left(\mathrm{c}, \mathrm{c}^{\prime}\right)-0.9 \mathrm{~V}$ vs $\mathrm{Ag} / \mathrm{AgCl}$, followed by annealing process at $550{ }^{\circ} \mathrm{C}$ for $60 \mathrm{~min}$. 


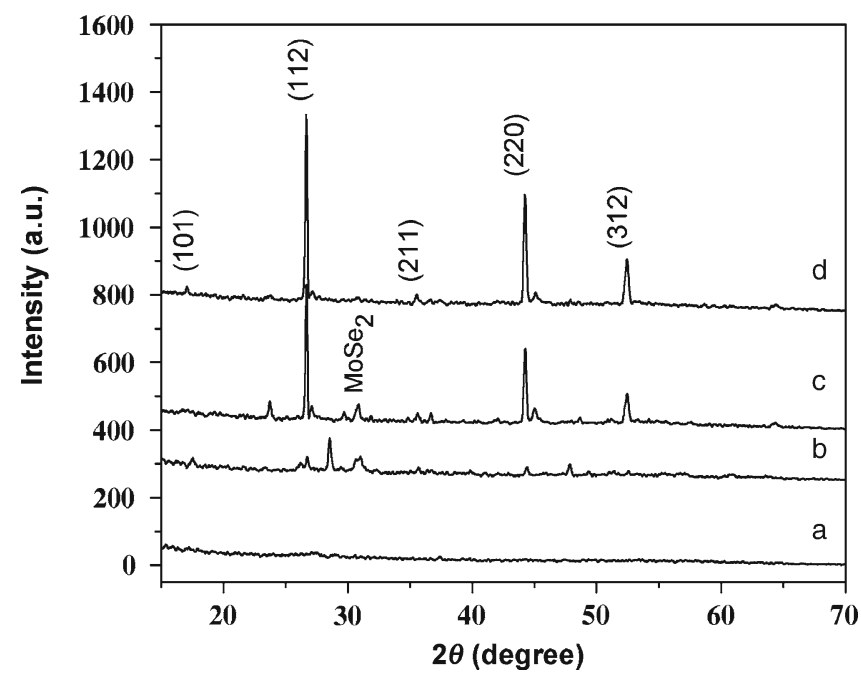

Figure 6. XRD patterns of typical CIGS films with plane indices corresponding to chalcopyrite structure: (a) as-deposited, postannealed films grown at (b) $-0.3 \mathrm{~V},(\mathbf{c})-0.5 \mathrm{~V}$ and $(\mathbf{d})-0.9 \mathrm{~V}$ vs $\mathrm{Ag} / \mathrm{AgCl}$.

in figure 6. XRD patterns of the films deposited at -0.3 and $-0.5 \mathrm{~V}$ (patterns $\mathrm{b}$ and $\mathrm{c}$ ) contain an additional peak at $31^{\circ}$, which belongs to $\mathrm{MoSe}_{2}$ structure. $\mathrm{MoSe}_{2}$ phase was formed in these films during annealing process due to the exceeding concentration of Se.

\section{Conclusions}

In this study, we have studied the deposition mechanism of the CIGS layer by using the cyclic voltammetry technique. We have also studied the dependence of composition on the deposition potential. Variation of concentration of each constituent was found to be in good agreement with CV data. The underpotential deposition mechanism of $\mathrm{Cu}-\mathrm{Se}$ and In-Se phases was observed in voltammograms of binary and quaternary systems. A suitable potential range from -0.8 to $-1.0 \mathrm{~V}$ and an appropriate concentration of electrolyte bath were found for obtaining films with desired and stable stoichiometry. Further studies are still needed for better understanding of CIGS layer deposition as well as for improvement in the sample morphology.

\section{Acknowledgement}

This work was supported by project NAFOSTED 103.02.59.09.

\section{References}

Abrantes I M, Araujo L V and Veli D 1995 Miner. Eng. 81467

Bhatacharya R N, Batchelor W, Grannata J E, Hasoon H, Wiensner H, Ramanathan K, Keane J and Noufi R N 1998 Sol. Energy Mater. Sol. C. 5583

Bhatacharya R N, Hiltner J F, Batchelor W, Contreras M A, Noufi R N and Sites J R 2000 Thin Solid Films 361396

Fernandez A M and Bhatacharya R N 2005 Thin Solid Films 47410 Friedfeld R, Raffelle R D and Mantovani J G 1999 Sol. Energy Mater. C. $\mathbf{5 8} 375$

Ganchev M, Kois J, Kaelin M, Bereznev S, Tzvetkova E, Volubuzeva O, Stratieva N and Tiwari A 2006 Thin Solid Films 511-512 325

Hermann A M, Wesfall R and Wind R 1998 Sol. Energy Mater. C. 52355

Kampmann A, Sittinger V, Rechid J and Reineke-Koch R 2000 Thin Solid Films 361-362 309

Kampmann A, Rechid J, Raitzig A, Wulff S, Mihhalova M, Thyen R and Kaberlah K 2003 Mater. Res. Soc. Symp. Proc. 763323

Kang F, Ao J, Sun G, He Q and Sun Y 2010 Curr. Appl. Phys. 10886

Lai Y, Liu F, Zhang Z, Liu J, Li Y, Kuang S, Li J and Liu Y 2009 Electrochim. Acta $\mathbf{5 4} 3004$

Liu J, Liu F, Lai Y, Zhang Z, Li J and Liu Y 2011 J. Electroanal. Chem. $\mathbf{6 5 1} 191$

Massaccesi S, Sanchez S and Vedel J 1996 J. Electroanal. Chem. 41295

Mishra K K and Rajeshwar K 1989 Electroanal. Chem. 271279

Repinst L, Contreras M A, Egaas B, Hart C De, Scharf J, Perkins C L, To B and Noufi R 2008 Prog. Photovolt. Res. Appl. 16235

Thouin L, Rouquette-Sanchez S and Vedel J 1993 Electrochim. Acta 382387

Zank J, Mehlin M and Fritz H P 1996 Thin Solid Films 286259

Zhang L, Jiang F D and Feng J Y 2003 Sol. Energy Mater. C. 80483 